\title{
The homotrimeric structure of HtrA2 is indispensable for executing its serine protease activity
}

\author{
Min-Kyung Nam ${ }^{1,2 *}$, Young-Mo Seong ${ }^{1,3 *}$, \\ Hyo-Jin Park ${ }^{1,3}$, Ju-Youn Choi ${ }^{1,4}$, \\ Seongman $\mathrm{Kang}^{3}$ and Hyangshuk Rhim ${ }^{1,2,5}$ \\ ${ }^{1}$ Research Institute of Molecular Genetics \\ ${ }^{2}$ Department of Biomedical Sciences \\ Catholic University \\ Seoul 137-701, Korea \\ ${ }^{3}$ School of Life Science and Biotechnology \\ Korea University \\ Seoul 136-701, Korea \\ ${ }^{4}$ Department of Biology \\ Sangmyung University \\ Seoul 110-743, Korea \\ ${ }^{5}$ Corresponding author: Tel, 82-2-590-2390; \\ Fax, 82-2-532-0575; E-mail, hrhim@catholic.ac.kr \\ ${ }^{*}$ These authors contributed equally to this work.
}

Accepted 14 December 2005

Abbreviations: HAX-1, HS1-associated protein X-1; HtrA, high temperature requirement $A$; mnd2, motor neuron degeneration 2; $\mathrm{XIAP}, \mathrm{X}$-linked inhibitor of apoptosis protein

\footnotetext{
Abstract

Serine protease activity of high temperature requrement 2 (HtrA2) is essential for promoting cell death, as well as for protecting against cellular stresses. An X-ray crystallographic study described the formation of a pyramid shaped homotrimer that is a proteolytically competent form of HtrA2; however, little is known about effects of the trimeric structure of HtrA2 on the natural substrates. In this study, we generated the HtrA2 protein that has a single point mutation at the homotrimerization motif to assess relationship between structure and the proteolytic activity of HtrA2 on its substrates. Using gel filtration, a native gel electrophoresis system, and a co-precipitation assay, we confirm that phenylalanine 149 in HtrA2 is a crucial determinant for the formation of the HtrA2 homotrimeric structure. Moreover, we described that the HtrA2 monomeric form abolished not only autoproteolytic activity, but also the proteolytic activity against XIAP (X-linked inhibitor of apoptosis protein) known as the HtrA2 substrate. Taken together, the results indicate that
}

the homotrimeric structure of HtrA2 is required for executing its serine protease activity.

Keywords: Omi serine protease; protein structure, tertiary; serine endopeptidases; structure-activity relationships; X-linked inhibitor of apoptosis protein

\section{Introduction}

An Escherichia coli (E. coli) HtrA (high temperature requirement $A$, also known as DegP) plays a role as a molecular chaperone at temperatures below $30^{\circ} \mathrm{C}$, and its proteolytic activity rapidly increases at temperatures above $30^{\circ} \mathrm{C}$ (Lipinska et al., 1989). HtrA is indispensable for $E$. coli cell survival by controlling its proteolytic activity to reduce the levels of unfolded or aggregated proteins at elevated temperatures (Lipinska et al., 1990; Skorko-Glonek et al., 1995; Spiess et al., 1999; Krojer et al., 2002).

The recent crystal structures of two members of the HtrA protein family, human $\mathrm{HtrA} 2$ and E. coli HtrA, provide insights into their structure-function relationship (Gray et al., 2000; Li et al., 2002; Maurizi, 2002; Kim and Kim, 2005). A functional $\mathrm{HtrA}$ protein forms a hexamer molecule assembled by staggered association of two trimeric rings. Each monomer of $\mathrm{HtrA}$ consists of three functionally distinct domains, a conserved catalytic domain of serine proteases and two $\mathrm{C}$-terminal PDZ domains (Faccio et al., 2000; Suzuki et al., 2001). HtrA2 (also known as Omi), one of human homologues of HtrA, has initially been identified as a stress-activated protease (Schlieker et al., 2004). A monomeric structure of mature HtrA2 (amino acid residues 134-458) consists of functionally defined structures, a trimerization motif (aa 146-151), a C-terminal PDZ domain (aa 364-445), and a central serine protease domain (aa 150-343) that contains the His-198, Asp 228, and Ser-306 catalytic triad in its conserved active site (Faccio et al., 2000; Gray et al., 2000; Suzuki et al., 2001; Li et al., 2002). Each of serine protease domains in HtrA2 is involved in mediating the formation of a pyramid-shaped homotrimer. The $\mathrm{PDZ}$ domains in E. coli HtrA appear to facilitate entry of the damaged or denatured proteins into the proteolytic active sites (Maurizi, 2002; Schlieker et al., 2004; Kim and Kim, 2005). In contrast, the PDZ domains in $\mathrm{HtrA} 2$ are hindered substrate access to the proteolytic active sites, as supported by evi- 
dence that deletion of the PDZ domain from $\mathrm{Htr}$ 2 relieves inhibition and thus increasing the proteolytic activity (Martins et al., 2003; Gupta et al., 2004).

Previous biochemical study exhibited that HtrA2 has proteolytic activity on $\alpha$-casein, $\beta$-casein, hyaluronidase, and glycoprotein $\alpha 1$ acid that were identified by screening 40 proteins (Gray et al., 2000). Unlike bacterial HtrA, several lines of evidences describe a regulatory function of mature HtrA2 in either caspase-dependent or -independent apoptotic cell death (Suzuki et al., 2001; Hegde et al., 2002; van Loo et al., 2002; Blink et al., 2004; Suzuki et al., 2004). In conjunction with these results, IAP (inhibitor of apoptosis), apollon, HAX-1 (HS1-associated protein X-1), and PED/PEA-15, known as anti-apoptotic proteins that regulate programmed cell death, were reported as HtrA2 substrates (Srinivasula et al., 2003; Cilenti et al., 2004; Trencia et al., 2004; Sekine et al., 2005).

Structural and biochemical studies showed that the monomeric HtrA2 form generated by converting phenylalanine 149 to aspartic acid in the trimerization motif disrupted its endoproteolytic activity (Li et al., 2002). To date, however, no in depth studies have examined whether this HtrA2 mutant virtually forms a monomeric structure, and thereby influencing the proteolytic activity on the substrates. Here we showed detailed experimental evidences that phenylalanine at residue 149 is important in mediating trimeric assembly of HtrA2, by using gel filtration and native gel electrophoretic analyses as well as GST- and FLAG-tagged HtrA2 co-precipitation assay. In addition, we demonstrate that homotrimerization of $\mathrm{HtrA} 2$ plays a critical role in its serine proteolysis activity.

\section{Materials and Methods}

\section{Plasmid construction}

The QuickChange Site-Directed Mutagenesis Kit
A

HtrA2 \begin{tabular}{c|c|c|c|}
\hline MTS & TM & Protease domain & PDZ \\
\hline & $\begin{array}{c}\text { QYNFIA } \\
\text { Trimerization motif }\end{array}$ & 458 \\
& &
\end{tabular}

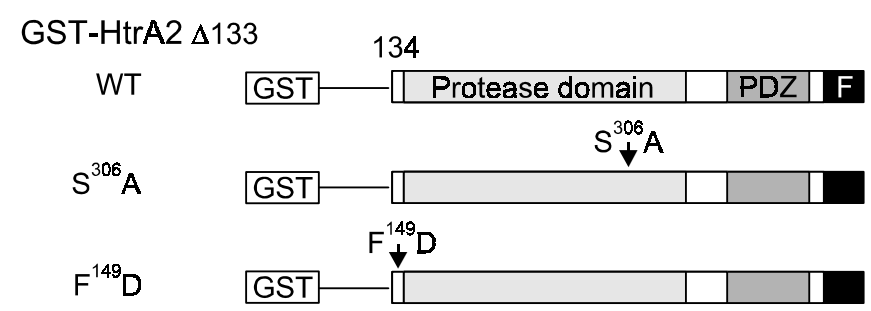

B

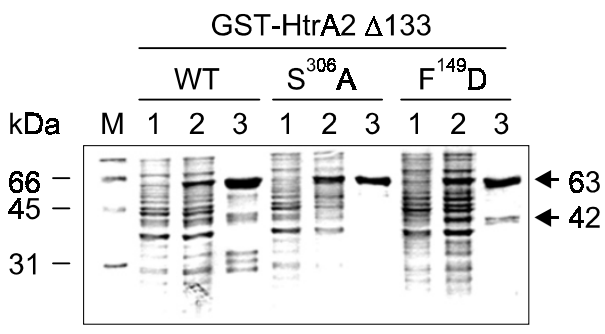

C

\begin{tabular}{|c|c|}
\hline Human & GGAULLLLEGGGRGPP AULAAVP SPPPASPRSQYNF' TADV \\
\hline Mouse & YLLLITGLGRGLSTYLAAUP APPPT SPRSQXNF I ADV \\
\hline Rat & GGAVLLLLLGHGRGP STVLAAVP APPPT SPR SONNF' TADV \\
\hline Bovine & GPP AVLAS ULGSPPT SPRSQYNE TADV \\
\hline pig & GGAULLLLEGGGRGPP AULAAULS SPPT SPRSQXNF TADY \\
\hline rild boar & GGAULLLLWGGGRGPP AULAAULS SPPT SPRSOYNF TADV \\
\hline Chimpanzee & SARULCXCC-GRGRUPP AULAAVPDPPPLSPRSQXNF TADV \\
\hline Ch: & PPGSPRARE WF IIADV \\
\hline ohila & MT----GRRRDFNE' IFDV \\
\hline osquito & QQXNF TADA \\
\hline
\end{tabular}

Figure 1. Expression and purification of the GST-HtrA2 proteins (A) Schematic representation of the GST-HtrA2 constructs. Human HtrA2 consists of functional domains: MTS, mitochondrial target sequence (aa 1-40), TM, transmembrane domain (aa 105-123), trimerization motif (aa 146-151), protease domain (aa 150-343), and PDZ domain (aa 364-445). GST-HtrA2 $\Delta 133$ : wild-type (WT), a catalytic mutant (S ${ }^{306}$ A) by replacing the catalytic serine residue with alanine at residue 306 , and a structural mutant $\left(F^{149} \mathrm{D}\right)$ by substitution of phenylalanine to aspartate at residue 149 in the trimerization motif. (B) Expression and purification of HtrA2 $\Delta 133$ as GST fusion proteins. WT, $\mathrm{S}^{306} \mathrm{~A}$, and $\mathrm{F}^{149} \mathrm{D}$ expressed in E. coli were purified by specific binding to glutathione-Sepharose 4B beads. Proteins were resolved by $15 \%$ SDS-PAGE and visualized by staining with Coomassie Brilliant Blue. Lane M is molecular weight standard; lanes 1 shows cell lysates of $E$. coli cultures before IPTG induction; lanes 2 shows cell lysates of $E$. coli cultures after IPTG induction; and lanes 3 shows $63-\mathrm{kDa}$ GST-HtrA2 proteins selectively bound to glutathione-Sepharose 4B beads. (C) Sequence alignment of the trimerization motif (shaded box) of the HtrA2 orthologs. 
A

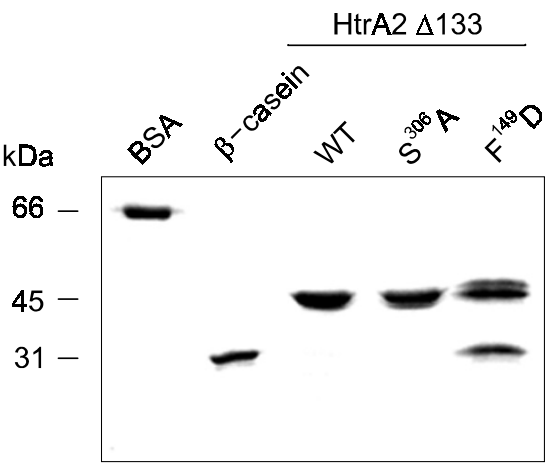

B

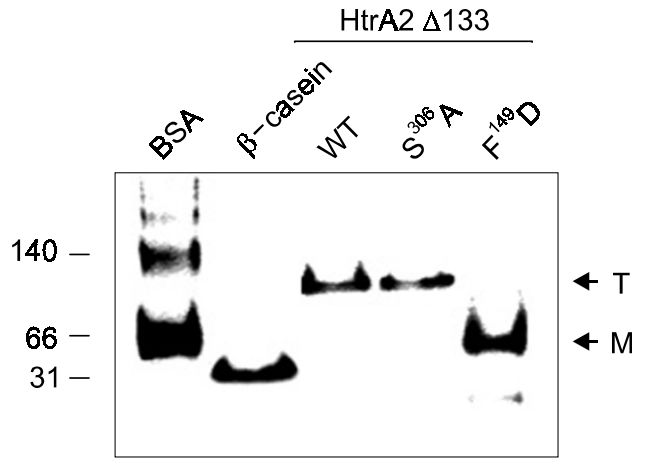

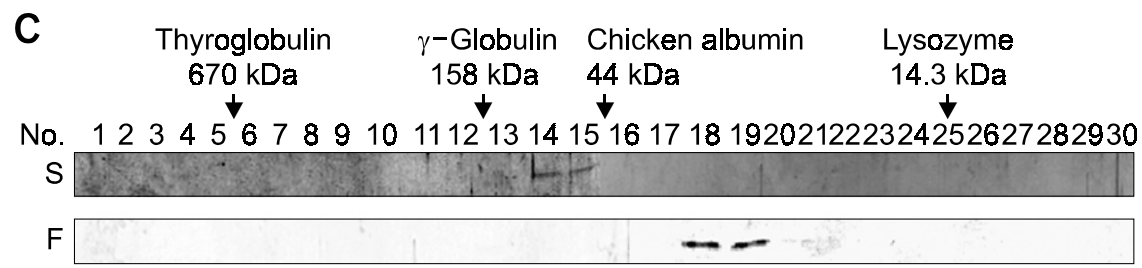

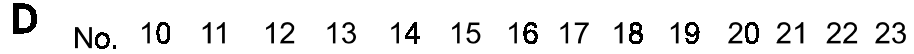

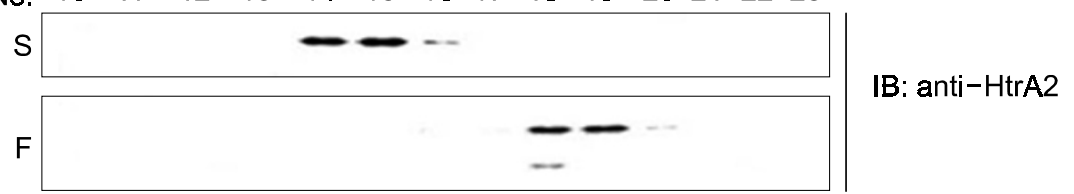

Figure 2. Effect of $F^{149}$ on the homotrimerization of $H t r A 2$. The thrombin cleaved proteins, $W T, S^{306} A$, and $F^{149} D$ were separated on a $15 \%$ SDS-polyacrylamide gel (A) and on a $10 \%$ native polyacrylamide gel (B) and visualized by staining with Coomassiae Brilliant Blue. $\mathrm{T}$ and $\mathrm{M}$ indicate the trimeric and monomeric form of $\mathrm{HtrA} 2 \Delta 133$, respectively. (C) Gel filtration analysis of the HtrA2 proteins. The protein samples were filtered through a Superose 12 gel filtration column. Fractions (1-30) were collected and analyzed on a 15\% SDS-polyacrylamide gel, and the proteins were visualized by staining with Coomassie Brilliant Blue. (D) Eluted samples in fractions 10-23 were resolved by $15 \%$ SDS-PAGE, followed by immunoblot analysis with anti-HtrA2 antibody. No, S, and F indicate numbers of column fractions, $\mathrm{S}^{306} \mathrm{~A}$, and $\mathrm{F}^{149} \mathrm{D}$, respectively.

(Stratagene, La Jolla, CA) was used according to manufacturer's instructions to generate a monomeric structural mutant $\left(\mathrm{F}^{149} \mathrm{D}\right)$, with substitution of aspartic acid for phenylalanine at residue 149. The mutagenic oligonucleotides used in this study are 5'CGGAGTCAGTACAACGACATCGCAGATG-3' and 5'-CATCTGCGATGTCGTTGTACTGACTCCG-3' (substitution of TT to GA in bold; TTC and GAC corresponding to phenylalanine and aspartic acid, respectively). For expression of HtrA2 $\Delta 133$ as GST fusion in mammalian cells, the HtrA2 (aa 134-358) fragment was removed from the pHtrA2-FLAG (WT) plasmid by digestion with Bg/ll (5') and Xhol (3') restriction enzymes and inserted into the pcDNA3GST tag plasmid (Lee et al., 2005), designated pcGST-HtrA2 (Figure 2B). Details of all plasmid constructs are available upon request. The sequence integrity of all plasmid constructs was verified by DNA sequencing with the $A B I$ Prism
BigDye Terminator Cycle Sequencing Ready Reaction Kit (Applied Biosystems, Foster City, CA).

\section{Purification of recombinant HtrA2 expressed in E. coli}

Expression of GST-HtrA2 $\Delta 133$ proteins in BL21 cells was induced with $0.1 \mathrm{mM}$ isopropyl-1-thio- $\beta$ D-galactoside (IPTG) as described previously (Seong et al., 2004). The cultures were collected by centrifugation, and the bacterial pellets were resuspended in lysis buffer (50 mM Tris- $\mathrm{HCl}, \mathrm{pH} 8.0,120$ $\mathrm{mM} \mathrm{NaCl}$, and $0.5 \%$ Nonidet P-40) containing $7 \mathrm{mM}$ dithiothreitol (DTT) and $2 \mu \mathrm{g} / \mathrm{ml}$ of the protease inhibitors, aprotinin and leupeptin. The GST-HtrA2 $\Delta 133$ proteins were purified by selective binding to glutathione-Sepharose 4B beads (Amersham Pharmacia Biotech., Piscataway, NJ) under non-denaturing condition and resolved by $15 \%$ SDS-PAGE. 
For purification of $\mathrm{HtrA} 2$, the $\mathrm{HtrA} 2$ protein-bound beads were resuspended in $100 \mu$ of cleavage buffer $(50 \mathrm{mM}$ Tris- $\mathrm{HCl}, \mathrm{pH}$ 7.6, $20 \mathrm{mM} \mathrm{KCl}$, and 1 $\mathrm{mM}$ DTT) and incubated with $5 \mathrm{U}$ of human thrombin (Amersham Pharmacia Biotech.) for $1 \mathrm{~h}$ at room temperature. Protein purity and concentrations were estimated by comparison with BSA of known concentration in $15 \%$ SDS-PAGE followed by staining of the gel with Coomassie Brilliant Blue dye. Purified proteins were stored at $-70^{\circ} \mathrm{C}$ in a final glycerol concentration of $20 \%$ and $7 \mathrm{mM}$ DTT.

\section{Gel electrophoresis under a non-denaturing condition}

Laemmli discontinuos system without SDS was used for a native gel system (Bollag et al., 1996). Protein concentrations were adjusted to $1 \mu \mathrm{g} / \mathrm{ml}$ with loading buffer $(12 \mathrm{mM}$ Tris- $\mathrm{HCl}, \mathrm{pH} 6.8,5 \%$ glycerol, $0.02 \%$ bromophenol blue), and the proteins were separated by running a $10 \%$ native gel for $2 \mathrm{~h}$ at $10 \mathrm{~mA}$. The protein bands were detected by staining of the gel with Coomassie Brilliant Blue dye. The electrophoretic mobility of proteins was analyzed by comparison with proteins with known molecular masses (Tanaka et al., 2001).

\section{Gel filtration chromatography}

The HtrA2 proteins purified by selective binding to glutathione-4B beads were applied to a Superose 12 HR 10/30 column in a Pharmacia FPLC System. The column was equilibrated and run in PBS at a flow rate of $0.5 \mathrm{ml} / \mathrm{min}$ at $25^{\circ} \mathrm{C}$, and $400 \mu$ fractions were collected and resolved by $15 \%$ SDS-PAGE. The size difference between the monomeric and trimeric $\mathrm{HtrA} 2$ was assessed by the elution profile of molecular mass standards on the gel filtration.

\section{Cell culture and transfection}

Human embryonic kidney 293 cells (American Type Culture Collection, Manassas, VA), which yield a high transfection efficiency, were maintained at $37^{\circ} \mathrm{C}$ in a humidified $5 \% \mathrm{CO}_{2}$ incubator in Dulbecco's modified Eagle minimum essential medium (DMEM) (Invitrogen, Carlsbad, CA) supplemented with 10\% $(\mathrm{v} / \mathrm{v})$ heat-inactivated fetal bovine serum (Invitrogen.), $50 \mathrm{U} / \mathrm{ml}$ penicillin and $50 \mu \mathrm{g} / \mathrm{ml}$ streptomycin (Invitrogen). For all transfections into 293 cells, the LipofectAMINE reagent (Invitrogen) was used according to the manufacturer's instructions. Cell extracts were prepared at $24 \mathrm{~h}$ post-transfection, and the $\mathrm{HtrA} 2$ trimeric assembly was analyzed by coprecipitation assay.

\section{Immunoblot (IB) and co-precipitation assays}

For co-precipitation, the transfected cells were homogenized in lysis buffer [0.2\% digitonin, $20 \mathrm{mM}$ HEPES, $100 \mathrm{mM} \mathrm{KCl,} 10 \mathrm{mM} \mathrm{CaCl}$, $50 \mathrm{mM} \mathrm{MgCl}_{2}$ ] containing protease inhibitors $(10 \mu \mathrm{g} / \mathrm{ml}$ leupeptin, $10 \mu \mathrm{g} / \mathrm{ml}$ aprotinin, and $0.1 \mathrm{mM}$ PMSF) and incubated for $1 \mathrm{~h}$ on ice. Protein extracts $(1 \mathrm{mg})$ were incubated with glutathione-sepharose 4B beads for $1 \mathrm{~h}$ at $4{ }^{\circ} \mathrm{C}$. The resulting $\mathrm{HtrA} 2$ protein bound beads were resolved by $15 \%$ PAGE, immunoblotted with anti-HtrA2 antibody, and then detected with the Enhanced Chemiluminescent (ECL) immunoblotting system as described by the manufacturer (Amersham Pharmacia Biotech.).

\section{Endoproteolytic cleavage assays}

For cleavage of $\beta$-casein as an exogenous substrate, $10 \mu \mathrm{M} \beta$-casein was incubated with the indicated GST-HtrA2 bound to beads to final concentrations of $100 \mathrm{nM}$ in a total $100 \mu$ of cleavage buffer (50 mM Tris- $\mathrm{HCl}, \mathrm{pH} 7.5,1 \mathrm{mM}$ DTT) for the indicated time at $37^{\circ} \mathrm{C}$. The reaction mixtures were resolved by $15 \%$ SDS-PAGE, and the cleavage of $\beta$-casein was visualized by staining with Coomassie Brilliant Blue dye.

$\left[{ }^{35} \mathrm{~S}\right]$ Methionine-labeled XIAP and full-length HtrA2 $S^{306} A$ were generated with the TNT T7 coupled reticulocyte lysate system following the manufacturer's instructions (Promega, Madison, WI). Cleavage reactions were initiated by adding wildtype or mutant of $\mathrm{HtrA} 2 \Delta 133$ to a final concentration of $0.5 \mu \mathrm{M}$ in $30 \mu$ of cleavage buffer (50 $\mathrm{mM}$ Tris- $\mathrm{HCl}, \mathrm{pH} 7.5,1 \mathrm{mM}$ DTT) for the indicated time at $37^{\circ} \mathrm{C}$. The reaction products were analyzed by $15 \%$ SDS-PAGE, and gels were dried and exposed to X-ray film.

\section{Results and Discussion}

\section{Rapid purification of human HtrA2 recombinant proteins expressed in $E$. coli as GST-fusion}

To characterize the structure-activity relationship of $\mathrm{HtrA2}$, we used to GST-HtrA2 $\Delta 133 \mathrm{WT}, \mathrm{S}^{306} \mathrm{~A}$, and $F^{149} \mathrm{D}$ constructs (Figure $1 \mathrm{~A}$ ). The recombinant GSTHtrA2 $\triangle 133$ proteins expressed from these constructs were purified with glutathione-Sepharose 4B beads, in a rapid method that has been previously described (Figure 1B) (Seong et al., 2004). Most of the GST-HtrA2 $\Delta 133$ proteins purified had molecular mass of approximately $63 \mathrm{kDa}$. Several distinct fragments of lower molecular masses were also detected in WT containing the trimerization motif and the catalytic serine residue; whereas, these fragments were barely detected in both $S^{306} A$ and 
A cGST-HtrA2
\begin{tabular}{|l|l|l|l|l|}
\hline CMV & 458 \\
\hline
\end{tabular}

HtrA2-FLAG (WT, $\left.\mathrm{S}^{306} \mathrm{~A}, \mathrm{~F}^{149} \mathrm{D}\right)$

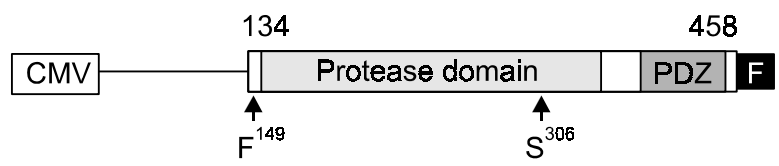

B
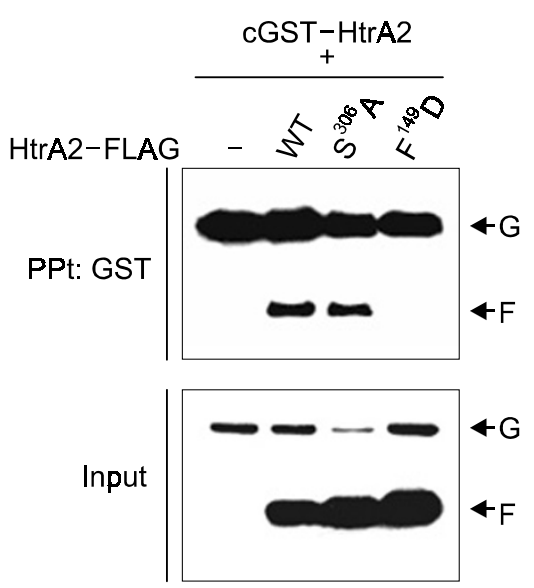

IB: anti-HtrA2

Figure 3. $\mathrm{F}^{149}$ is essential for the $\mathrm{Htr} \mathrm{A} 2$ trimeric assembly in vivo. (A) Schematic representation of $\mathrm{Htr} A 2 \Delta 133$ constructs for a mammalian expression system. The cGST-HtrA2 and HtrA2-FLAG constructs were tagged with the GST- or FLAG-epitopes at the N- or C-termini, respectively. (B) The $F^{149} D$ mutant forms a monomric structure. A plasmid encoding the GST-HtrA2 protein was co-transfected into 293 cells with the indicated plasmid encoding the C-terminal FLAG tagged HtrA2, WT, $S^{306} \mathrm{~A}$, or $F^{149} \mathrm{D}$. The levels of HtrA2 proteins were determined by IB analyses of whole cell extracts with anti-HtrA2 antibody (input). The GST-HtrA2 protein was precipitated with glutathione-Sepharose 4B beads (PPt), and the resulting precipitates were immunoblotted with anti-HtrA2 antibody (upper panel). $\mathrm{G}$ and $\mathrm{F}$ indicate GST-HtrA2 and HtrA2-FLAG, respectively.

$\mathrm{F}^{149} \mathrm{D}$, in which the catalytic site and the trimerization motif were disrupted, respectively. The result indicates that the phenylalanine residue in the trimerization motif is as important as the catalytic serine residue for self-proteolytic processing activity of HtrA2. Nonetheless, some differently migrating band with molecular mass of approximately $42 \mathrm{kDa}$ appeared in $\mathrm{F}^{149} \mathrm{D}$, probably due to the presence of the catalytic triad of serine proteases.

\section{Phe-149 serves as the major determinant of formation of the HtrA2 homotrimer}

The trimerization motif, $\mathrm{QYN}^{149} \mathrm{FIA}$, is identical in eight mammalian $\mathrm{HtrA} 2$ orthologs, and amino acid residues, $\mathrm{N}^{149} \mathrm{FIA}$, are conserved in even two invertebrates, Drosophila and mosquito (Figure 1C). To investigate role of the conserved phenylalanine 149 in the trimeric assembly of $\mathrm{HtrA} 2$, we analyzed the electrophoretic mobility of the HtrA2 proteins in both denaturing and non-denaturing gels (Figure 2). To exclude the possibility of self-oligomeric forms through the GST moiety of the fusions, the thrombin-cleaved HtrA2 proteins were collected by elution from the GST-bound beads and resolved by $15 \%$ SDS-PAGE (Figure 2A) and 10\% non-denaturing gel (Figure 2B). All three HtrA2 proteins, WT, $\mathrm{S}^{306} \mathrm{~A}$, and $\mathrm{F}^{149} \mathrm{D}$, migrated at an approximate molecular mass of $36 \mathrm{kDa}$ through SDS-PAGE. In contrast, $F^{149} D$ revealed molecular mass close to 30 $\mathrm{kDa}$, and $\mathrm{WT}$ and $\mathrm{S}^{306} \mathrm{~A}$ appeared to an apparent molecular mass between those of already known 66- and $140 \mathrm{kDa}$ proteins, in a native gel system. To further analyze the structural difference between $\mathrm{S}^{306} \mathrm{~A}$ and $\mathrm{F}^{149} \mathrm{D}$, the thrombin-cleaved HtrA2 proteins were filtered through a Superose $12 \mathrm{FPLC}$ column, and eluted samples were resolved by $15 \%$ SDS-PAGE (Figure $2 \mathrm{C}$ and D). A significant portion of $S^{306} A$ eluted in a trimer peak, whereas $F^{149} D$ was detected in a monomer peak from gel filtration column, as compared the elution pattern of standard of known molecular mass: thyroglobulin $(670 \mathrm{kDa})$, $\gamma$-globulin (158 kDa), chicken albumin (44 kDa), and lysozyme $(14.3 \mathrm{kDa})$. The results indicate that $\mathrm{HtrA} 2$ exists as a homotrimeric structure, and this structure is disrupted by altering the trimerization motif of HtrA2.

To verify whether the trimerization motif plays a role in the formation of the HtrA2 homotrimeric complex in vivo, $\mathrm{N}$-terminal GST- and $\mathrm{C}$-terminal FLAG- tagged HtrA2 proteins were co-expressed in 293 cells (Figure 3 ). The cGST-HtrA2 protein was precipitated with glutathione-Sepharose 4B beads, and self-interaction of $\mathrm{HtrA} 2$ was analyzed by IB assay with anti-HtrA2 antibody (Figure $3 \mathrm{~B}$ ). Both the $36 \mathrm{kDa} W T$ and $\mathrm{S}^{306} \mathrm{~A}$ proteins co-precipitated along with the $63-\mathrm{kDa}$ cGST-HtrA2 protein; whereas, the $36-k D a F^{149} \mathrm{D}$ protein was not detected. The replacement of aspartic acid residue at phenylalanine 149 in HtrA2 completely abolished the formation of a homotrimer, indicating that phenylalanine is also essential for the homotrimeric structure of $\mathrm{HtrA} 2$ in vivo. 
A

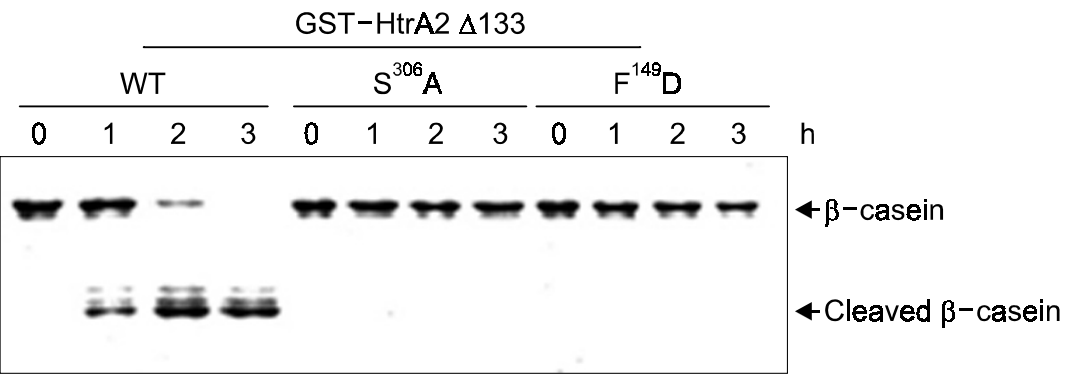

B

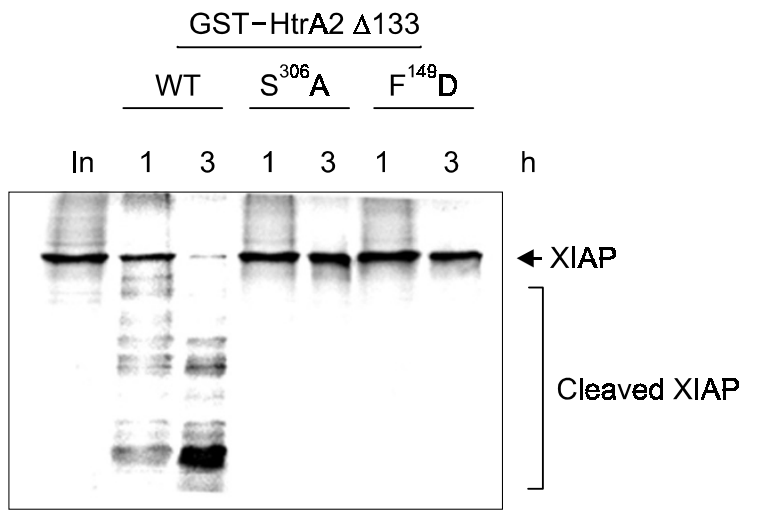

Trimeric structure of HtrA2 is required for its serine protease activity

To assess functional significance of the trimeric form of HtrA2, we compared endoproteolytic activity of WT and $F^{149} D$ by using $\beta$-casein as an exogenous substrate (Figure 4A). WT exhibited endoproteolytic activity against $\beta$-casein, whereas the endoproteolytic activity of $F^{149} D$ against $\beta$-casein was completely abrogated as a comparable level of the catalytically inactive mutant $\mathrm{S}^{306} \mathrm{~A}$. The result demonstrates that phenylalanine 149 is important not only for the formation of a homotrimer, but also for the HtrA2 serine protease activity.

To further analyze the homotrimeric structure of $\mathrm{HtrA} 2$ necessary to degrade XIAP as a natural substrate, $\left.{ }^{35} \mathrm{~S}\right]$ Met-labeled XIAP was incubated with WT, $S^{306} A$, or $F^{149} \mathrm{D}$ for the indicated time at $37^{\circ} \mathrm{C}$ (Figure 4B). Several distinct protein fragments were detected only in WT, but not in the proteolytically inactive $\mathrm{S}^{306} \mathrm{~A}$ and the monomeric $\mathrm{F}^{149} \mathrm{D}$. The results indicate that the formation of the homotrimer is the requisite for the XIAP processing by the serine protease activity of $\mathrm{HtrA} 2$.

\section{Trimeric structure of HtrA2 is essential for autocatalytic processing of HtrA2}

Our previous study demonstrated that autocatalytic processing of HtrA2 is crucial for induction of apoptosis through the relief of XIAP-mediated caspase
Figure 4. Trimer formation of HtrA2 is indispensable for its serine protease activity. (A) An analysis of endoproteolytic activity of $F^{149} D$. $\beta$-Casein was incubated with WT, $S^{306} \mathrm{~A}$, and $\mathrm{F}^{149} \mathrm{D}$ for the indicated times at $37^{\circ} \mathrm{C}$. The reaction samples were resolved by $15 \%$ SDS-PAGE and visualized by staining with coomassie brilliant blue. (B) Effect of the HtrA2 trimer on proteolytic cleavage of XIAP. In vitro cleavage reaction, $\left.{ }^{35} \mathrm{~S}\right]$ Met-labeled XIAP was incubated without (In; Input) or with WT, $S^{306} A$, or $F^{149} D$ for the indicated times. The reaction products were analyzed by $15 \%$ SDS-PAGE and visualized by autoradiography.

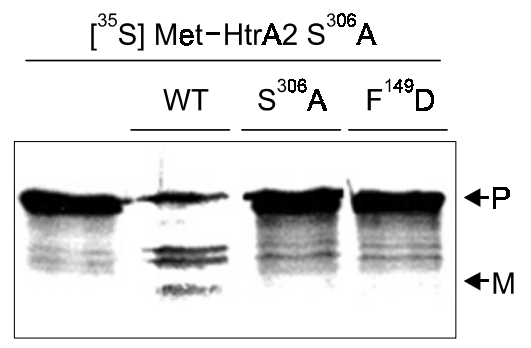

Figure 5. Trimerization of HtrA2 is essential for its autocatalytic processing activity. An $\left[{ }^{35} \mathrm{~S}\right]$ Met-labeled, proteolytically inactive $\left(\mathrm{S}^{306} \mathrm{~A}\right)$ form of full-length HtrA2 was incubated with WT, $S^{306} A$, or $F^{149} \mathrm{D}$ for 1 and $3 \mathrm{~h}$ at $37^{\circ} \mathrm{C}$. Input indicates $\mathrm{HtrA2}\left(\mathrm{S}^{306} \mathrm{~A}\right)$ only. The reaction mixtures were resolved on $15 \%$ SDS-PAGE, the cleavage patterns were visualized by autoradiograph. $\mathrm{P}$ and $\mathrm{M}$ indicate the precursor and mature form of $\mathrm{Htr} A 2\left(\mathrm{~S}^{306} \mathrm{~A}\right)$, respectively.

inhibition (Seong et al., 2004). We assessed whether the HtrA2 trimeric structure is required for the autocatalytic processing of $\mathrm{HtrA} 2$ by using an in vitro cleavage assay. Full-length $\left[{ }^{35} \mathrm{~S}\right]$ Met-labeled HtrA2 $S^{306} \mathrm{~A}$ used as a substrate was incubated with the GST-HtrA2 $\Delta 133 \mathrm{WT}, \mathrm{S}^{306} \mathrm{~A}$, or $\mathrm{F}^{149} \mathrm{D}$ (Figure 5). We observed distinct fragment with molecular mass of approximately $36 \mathrm{kDa}$ in WT. In contrast, production of the $36 \mathrm{kDa}$ protein fragment was completely abolished in $\mathrm{F}^{149} \mathrm{D}$ as a comparable level in the catalytically inactive mutant $\mathrm{S}^{306} \mathrm{~A}$, suggesting that the trimeric assembly of HtrA2 is necessary for its 
maturation in an intermolecular manner.

A previous X-ray crystallographic study described that the homotrimeric assembly of HtrA2 observed in the crystal structure is consistent with the structure in solution using gel filtration chromatography (Li et al., 2002). Here, we add more experimental evidence for the formation of HtrA2 homotrimer. Moreover, we demonstrate that the HtrA2 homotrimerization is critical in proteolytic cleavage of an anti-apoptotic protein, XIAP, as well as in the HtrA2 autocatalytic processing. We previously showed that production of mature $\mathrm{HtrA} 2$ by autocatlytic processing is essential for induction of caspase-dependent cell death through antagonizing XIAP activity (Seong et al., 2004). Therefore, the replacement of aspartic acid residue at phenylalanine 149 in HtrA2 eliminated not only production of mature HtrA2 to expose the IAPbinding motif, but also the serine protease activity, suggesting that the HtrA2 trimerization might be crucial for caspase-dependent and -independent cell death (Suzuki et al., 2001; Hegde et al., 2002; van Loo et al., 2002; Blink et al., 2004; Suzuki et al., 2004). Our results would provide insight into understanding the relationship between structure and function of $\mathrm{HtrA} 2$, such as proteolytic and proapoptotic activities. Further work will be required to elucidate the molecular mechanisms in regulating the trimeric assembly of $\mathrm{HtrA} 2$ and in executing the $\mathrm{HtrA} 2$ function that is correlated with its structure.

Several lines of recent evidence suggest that $\mathrm{HtrA} 2$ might be associated with the pathogenesis of neurodegenerative disorders (Jones et al., 2003; Martins et al., 2004; Strauss et al., 2005). Deletion of $\mathrm{HtrA} 2$ showed neurological phenotype with selective loss of striatal neurons (Jones et al., 2003). Also, the missense mutation of the HtrA2 protease domain (S276C; substitution of cysteine for serine at residue 276) has been identified in the mnd2 mice (motor neuron degeneration 2), which exhibits progressive loss of striatal neurons, and eventually leading to motor dysfunction (Strauss et al., 2005). In addition, the missense mutation (G399S; substitution of serine for glycine at residue 399) has been recently identified in four patients with PD, but not in healthy controls (Martins et al., 2004). Our study may, therefore, provide a basis for understanding the pathophysiological function of $\mathrm{HtrA} 2$ involved in neurodegenerative disorders and for developing a new strategy to treat neurodegenerative disorders by regulating the $\mathrm{Htr} \mathrm{A} 2$ serine protease activity.

\section{Acknowledgment}

We thank Dae-Myung Jue for helpful suggestion and assistance with the FPLC system. This work was supported by a grant (20050401-034-658-135-03-
00) from BioGreen 21 Program, Rural Development Administration, Republic of Korea.

\section{References}

Blink E, Maianski NA, Alnemri ES, Zervos AS, Roos D, Kuijpers TW. Intramitochondrial serine protease activity of $\mathrm{Omi} / \mathrm{HtrA} 2$ is required for caspase-independent cell death of human neutrophils. Cell Death Differ 2004;11:937-9

Bollag DM, Rozycki MD, Edelstein SJ. Protein Methods, 2nd Ed, 1996, Wileyliss, NY

Cilenti L, Soundarapandian MM, Kyriazis GA, Stratico V, Singh S, Gupta S, Bonventre JV, Alnemri ES, Zervos AS. Regulation of HAX-1 anti-apoptotic protein by Omi/HtrA2 protease during cell death. J Biol Chem 2004;279:50295-301

Faccio L, Fusco C, Chen A, Martinotti S, Bonventre JV, Zervos AS. Characterization of a novel human serine protease that has extensive homology to bacterial heat shock endoprotease HtrA and is regulated by kidney ischemia. J Biol Chem 2000;275:2581-8

Gray CW, Ward RV, Karran E, Turconi S, Rowles A, Viglienghi D, Southan C, Barton A, Fantom KG, West A, Savopoulos J, Hassan NJ, Clinkenbeard H, Hanning $C$, Amegadzie B, Davis JB, Dingwall C, Livi GP, Creasy CL. Characterization of human HtrA2, a novel serine protease involved in the mammalian cellular stress response. Eur J Biochem 2000;267:5699-710

Gupta S, Singh R, Datta P, Zhang Z, Orr C, Lu Z, Dubois G, Zervos AS, Meisler MH, Srinivasula SM, Fernandes-Alnemri $\mathrm{T}$, Alnemri ES. The C-terminal tail of presenilin regulates Omi/HtrA2 protease activity. J Biol Chem 2004;279:4584454

Hegde R, Srinivasula SM, Zhang Z, Wassell R, Mukattash R, Cilenti L, DuBois G, Lazebnik Y, Zervos AS, FernandesAlnemri T, Alnemri ES. Identification of Omi/HtrA2 as a mitochondrial apoptotic serine protease that disrupts inhibitor of apoptosis protein-caspase interaction. J Biol Chem 2002;277:432-8

Jones JM, Datta P, Srinivasula SM, Ji W, Gupta S, Zhang Z, Davies E, Hajnoczky G, Saunders TL, Van Keuren ML, Fernandes-Alnemri T, Meisler MH, Alnemri ES. Loss of Omi mitochondrial protease activity causes the neuromuscular disorder of mnd2 mutant mice. Nature 2003;425:721-7

Kim DY, Kim KK. Structure and function of HtrA family proteins, the key players in protein quality control. J Biochem Mol Biol 2005;38:266-74

Krojer T, Garrido-Franco M, Huber R, Ehrmann M, Clausen T. Crystal structure of DegP $(\mathrm{HtrA})$ reveals a new proteasechaperone machine. Nature 2002;416:455-9

Lee SJ, Choi D, Rhim H, Kang S. E3 ubiquitin ligase RNF2 interacts with the $\mathrm{S6}^{\prime}$ proteasomal ATPase subunit and increases the ATP hydrolysis activity of S6'. Biochem J 2005;389:457-63

Li W, Srinivasula SM, Chai J, Li P, Wu JW, Zhang Z, Alnemri ES, Shi Y. Structural insights into the pro-apoptotic function 
of mitochondrial serine protease HtrA2/Omi. Nat Struct Biol 2002;9:436-41

Lipinska B, Fayet O, Baird L, Georgopoulos C. Identification, characterization, and mapping of the Escherichia coli htrA gene, whose product is essential for bacterial growth only at elevated temperatures. J Bacteriol 1989;171:1574-84

Lipinska B, Zylicz M, Georgopoulos C. The HtrA (DegP) protein, essential for Escherichia coli survival at high temperatures, is an endopeptidase. J Bacteriol 1990;172: 1791-7

Martins LM, Turk BE, Cowling V, Borg A, Jarrell ET, Cantley LC, Downward J. Binding specificity and regulation of the serine protease and PDZ domains of HtrA2/Omi. J Biol Chem 2003;278:49417-27

Martins LM, Morrison A, Klupsch K, Fedele V, Moisoi N, Teismann P, Abuin A, Grau E, Geppert M, Livi GP, Creasy CL, Martin A, Hargreaves I, Heales SJ, Okada H, Brandner $\mathrm{S}$, Schulz JB, Mak T, Downward J. Neuroprotective role of the Reaper-related serine protease HtrA2/Omi revealed by targeted deletion in mice. Mol Cell Biol 2004;24:9848-62

Maurizi MR. Love it or cleave it: tough choices in protein quality control. Nat Struct Biol 2002;9:410-2

Schlieker C, Mogk A, Bukau B. A PDZ switch for a cellular stress response. Cell 2004;117:417-9

Sekine K, Hao Y, Suzuki Y, Takahashi R, Tsuruo T, Naito M. HtrA2 cleaves Apollon and induces cell death by IAP-binding motif in Apollon-deficient cells. Biochem Biophys Res Commun 2005;330:279-85

Seong YM, Choi JY, Park HJ, Kim KJ, Ahn SG, Seong GH, Kim IK, Kang S, Rhim H. Autocatalytic processing of HtrA2/ Omi is essential for induction of caspase-dependent cell death through antagonizing XIAP. J Biol Chem 2004;279: 37588-96

Skorko-Glonek J, Wawrzynow A, Krzewski K, Kurpierz K, Lipinska B. Site-directed mutagenesis of the HtrA (DegP) serine protease, whose proteolytic activity is indispensable for Escherichia coli survival at elevated temperatures. Gene 1995;163:47-52
Spiess C, Beil A, Ehrmann M. A temperature-dependent switch from chaperone to protease in a widely conserved heat shock protein. Cell 1999;97:339-47

Srinivasula SM, Gupta S, Datta P, Zhang Z, Hegde R, Cheong N, Fernandes-Alnemri T, Alnemri ES. Inhibitor of apoptosis proteins are substrates for the mitochondrial serine protease Omi/HtrA2. J Biol Chem 2003;278:31469-72

Strauss KM, Martins LM, Plun-Favreau H, Marx FP, Kautzmann S, Berg D, Gasser T, Wszolek Z, Muller T, Bornemann A, Wolburg H, Downward J, Riess O, Schulz JB, Kruger R. Loss of function mutations in the gene encoding Omi/HtrA2 in Parkinson's disease. Hum Mol Genet 2005;14:2099-111

Suzuki Y, Imai Y, Nakayama H, Takahashi K, Takio K, Takahashi R. A serine protease, HtrA2, is released from the mitochondria and interacts with XIAP, inducing cell death. Mol Cell 2001;8:613-21

Suzuki Y, Takahashi-Niki K, Akagi T, Hashikawa T, Takahashi R. Mitochondrial protease Omi/HtrA2 enhances caspase activation through multiple pathways. Cell Death Differ 2004; $11: 208-16$

Tanaka K, Sawatani E, Shigueoka EM, Dias GA, Nakao HC, Arashiro F. Isolation of bovine plasma albumin by liquid chromatography and its polymerization for use in immunohematology. Braz J Med Biol Res 2001;34:977-83

Trencia A, Fiory F, Maitan MA, Vito P, Barbagallo AP, Perfetti $A$, Miele $C$, Ungaro $P$, Oriente $F$, Cilenti L, Zervos AS, Formisano $\mathrm{P}$, Beguinot $\mathrm{F}$. Omi/HtrA2 promotes cell death by binding and degrading the anti-apoptotic protein ped/pea-15. J Biol Chem 2004;279:46566-72.

van Loo G, van Gurp M, Depuydt B, Srinivasula SM, Rodriguez I, Alnemri ES, Gevaert K, Vandekerckhove J, Declercq W, Vandenabeele P. The serine protease Omi/ $\mathrm{HtrA} 2$ is released from mitochondria during apoptosis. Omi interacts with caspase-inhibitor XIAP and induces enhanced caspase activity. Cell Death Differ 2002;9:20-6 